\title{
PROSECUTORS WHO SEIZE TOO MUCH AND THE THEORIES THEY LOVE: MONEY LAUNDERING, FACILITATION, AND FORFEITURE
}

\author{
JON E. GORDON \\ INTRODUCTION
}

Since 1970, federal prosecutors have increasingly relied on civil and criminal forfeiture as tools for law enforcement. ${ }^{1}$ Statutes now provide for forfeiture to the government of assets connected to crimes such as money laundering, ${ }^{2}$ drug trafficking, ${ }^{3}$ racketeering, ${ }^{4}$ and mail and wire fraud, ${ }^{5}$ anong others. The goal of these statutes is to eliminate profit as an incentive for crime. ${ }^{6}$

Under 18 U.S.C. \& 981 , money involved in money laundering is an asset subject to forfeiture. ${ }^{7}$ Because money is fungible, prosecutors have special problems when money subject to forfeiture ("dirty" money) is mixed with money not connected to illegal activity ("clean" money). ${ }^{8}$ Rather than try to sort the dirty money from the clean, some federal prosecutors have tried to seize and forfeit $^{9}$ all of the money, based on a facilitation theory. ${ }^{10}$ Under

1. In 1970, criminal forfeiture was revived by the Racketeer Influenced and Corrupt Organizations statute (RICO), 18 U.S.C. $\$ \S 1961-1968$ (1988 \& Supp. IV 1992), and the Continuing Criminal Enterprise (CCE) statute, 21 U.S.C. \& 848 (1988 \& Supp. V 1993). See infra text accompanying notes 37-43. For examples of application of these and other forfeiture statutes, see David A. Kaplan et al., Where the Innocent Lose, NEWSWEEK, Jan. 4,1993 , at 42 .

2. 18 U.S.C. \& 981(a)(1)(A) (1988 \& Supp. IV 1992).

3. 21 U.S.C. \& 881(a) (1988 \& Supp. V 1993).

4. 18 U.S.C. \& 1963 (a)-(b) (1988 \& Supp. IV 1992).

5. 18 U.S.C. \& $981(\mathrm{a})(1)(\mathrm{D})$ (v)-(vi) (Supp. IV 1992).

6. See, e.g., S. REP. No. 225, 98th Cong., 2d Sess. 191 (1984), reprinted in 1984 U.S.C.C.A.N. 3182, 3374 (explaining reasons for bill expanding reach of existing forfeiture laws).

7. See United States v. $\$ 448,342.85,969$ F.2d 474,476 (7th Cir. 1992).

8. See, e.g., United States v. Banco Cafetero Panama, 797 F.2d 1154, 1158-62 (2d Cir. 1988) (discussing pooling of "traceable proceeds" from drug transactions with other funds).

9. Seizure and forfeiture are distinct events. Seizure occurs when the government 
this theory, the clean money facilitates the laundering of the dirty money by hiding it; in doing so, the clean money becomes involved in money laundering. Thus, the clean money is itself tainted and subject to forfeiture. ${ }^{11}$

This Note examines the broad facilitation theory advanced by some federal prosecutors and concludes that the theory gives prosecutors undesirable power to seize property. It argues that a narrower theory, conditioning forfeiture on the intent of the holder of the money, still would accomplish the goals of forfeiture, and that this theory is preferable because it would protect innocent persons from seizure and forfeiture and reduce the possibility of excessive forfeitures. The Note concludes that the intent-based standard would not impede efforts to deter crimes through forfeiture of assets used in their commission. The forfeiture laws provide ample means to seize assets of wrongdoers. Moreover, under this standard, the facts of many prior cases would produce the same results as under the facihtation theory, while innocent persons would be spared the cost and risk of defending their property.

Part I of this Note surveys the common law and statutory origins of forfeiture in the United States, emphasizing the growth of forfeiture in American law from a tool used to enforce the customs laws to the key weapon against the drug trade. Part II describes the facilitation theory and reviews the cases in which prosecutors tried to apply the theory. Part III argues that although a facilitation theory that disregards intent may result from a plausible construction of the federal forfeiture statute ${ }^{12}$ it is bad policy and conceptually infirm. Finally, the Note concludes that instead of applying the broad facilitation theory, courts ought to use an analysis based on the intent of the possessor of the inoney to determine forfeitability.

takes possession of an asset. BLACK's LAW DICTIONARY 1359 (6th ed. 1990). Forfeiture occurs when the owner is divested of his interest in the property. Id. at 650 .

10. See, e.g., United States v. Certain Accounts, 795 F. Supp. 391, 392-97 (S.D. Fla. 1992).

11. Id. at 396-97.

12. 18 U.S.C. \& 981 (1988 \& Supp. IV 1992). 


\section{THE DEVELOPMENT OF FORFEITURE IN THE UNITED STATES}

Although both civil and criminal forfeiture have long histories in the common law, they had very limited use in the United States until 1970. Simce then, statutes providing for criminal and civil forfeiture have proliferated. However, modern forfeiture law is still heavily influenced by past practices. For purposes of this Note, the most important artifact from the past is that even though forfeiture is intended partly to be pumishment for crimes, property owners receive little of the procedural protection given to criminal defendants.

\section{A. The History of Forfeiture}

By the time the U.S. Constitution was adopted, three kinds of forfeiture had been established under English law. ${ }^{13}$ The first required forfeiture of "inanimate object[s] directly or indirectly causing the accidental death of a King's subject."14 The object, called a deodand, was considered the guilty party, so the proceeding was in rem against the object, and the owner's innocence was not a defense. ${ }^{15}$ At first, the value of the object was used toward masses said for the good of the dead man's soul, or otlier cliaritable purposes, but the institution later became a source of revenue to the Crown, justified as a penalty for the owner's carelessness. ${ }^{16}$ The second kind of forfeiture was known as forfeiture of estate. On conviction for treason or felony, all real and personal property of a traitor or felon was forfeit. ${ }^{17}$ The ground was that breacli of the King's law merited denial of the riglit to own property. ${ }^{18}$ The third kind of forfeiture was statutory and applied to objects used in violation of the customs or revenue laws. ${ }^{19}$ For instance, the

13. See Calero-Toledo v. Pearson Yacht Leasing Co., 416 U.S. 663, 680-82 (1974) (surveying history of forfeiture at common law).

14. Id. at 680-81; Oliver Wendell Holmes, JR., The COMmON LAW 23-24 (The Belknap Press of Harvard University Press 1963) (1881).

15. Holmes, supra note 14 , at 23-24.

16. Jacob J. Finkelstem, The Goring Ox: Some Historical Perspectives on Deodands, Forfeitures, Wrongful Death, and the Western Nation of Sovereignty, 46 TEMP. L.Q. 169, 182-83 (1973).

17. EDWARD JENKS, A SHORT HISTORY OF ENGLISH LAW 41-42 (6th ed. 1949).

18. 1 William BlaCKSTONE, COMMENTARIES *289.

19. Id.; see 3 id. at $* 261-62$. In Calero-Toledo, the Court surmised that statutory forfeiture was "a product of the confluence and merger of the deodand tradition and the 
Navigation Acts of 1660 required goods to be shipped in English slips; violation resulted in forfeiture of botli the goods and the ship. ${ }^{20}$ The action was in rem against the object, and the owner lad to file a clain to contest the forfeiture. ${ }^{21}$ Moreover, an "act of an individual seaman, undertaken without the knowledge of the master or owner, could result in forfeiture of the entire slip."22 This harsh result was justified as a penalty on the ship's owner for negligently clioosing liis crew. ${ }^{23}$

Of these varieties of forfeiture, only the last, statutory forfeiture, took root in the United States. ${ }^{24}$ Deodand never became a part of American law. ${ }^{25}$ Forfeiture of estate for treason was constitutionally proscribed except during the traitor's natural life, ${ }^{26}$ and the First Congress abolished forfeiture of estate as punishment for felons. ${ }^{27}$ Statutory forfeiture, on the otlier hand, flourished both before and after the adoption of the Constitution; the type of property subject to forfeiture grew from that used in violation of customs and revenue laws to "ships and cargoes involved in customs offenses," eventually reaching "virtually any type of property that might be used in the conduct of a criminal enterprise." 28

Just as in England, statutory forfeiture in the United States applied in rem to the property involved. ${ }^{29}$ The property was con-

belief that the right to own property could be denied the wrongdoer." Calero-Toledo v. Pearson Yacht Leasing Co., 416 U.S. 663, 682 (1974).

20. Lawrence A. Harper, The English Navigation Laws: A SeventeenthCENTURY EXPERIMENT IN SOCIAl. ENGINEERING 111 (1939).

21. 3 BLACKSTONE, supra note 18 , at *261-62.

22. Austin v. United States, 113 S. Ct. 2801, 2807 (1993).

23. Id.

24. Id.

25. Calero-Toledo v. Pearson Yacht Leasing Co., 416 U.S. 663, 682 (1974). The Court cited Parker-Harris Co. v. Tate, 188 S.W. 54, 55 (Tenn. 1916), in which the Supreme Court of Tennessee described the doctrine as based on "superstition."

26. U.S. CoNsT. art. III, \& 3, cl. 2. In England, a consequence of treason was a permanent bar against the traitor's heirs' inheriting anything from the traitor. Due to the hardship this worked on the traitor's children, the Framers of the U.S. Constitution proscribed forfeiture except during the traitor's life. See Wallach v. Van Riswick, 92 U.S. 202, 210 (1875).

27. Act of April 30, 1790, ch. 9, 824,1 Stat. 112, 117.

28. Calero-Toledo, 416 U.S. at 683.

29. See, e.g., Dobbins's Distillery v. United States, 96 U.S. 395, 401 (1877) (observing that guilt attached to distillery without regard to owner's culpability beyond that implicit in decision to lease property to a wrongdoer). But cf. Austin v. United States, $113 \mathrm{~S}$. Ct. 2801,2809 (1993) (saying that the Court has never approved of a forfeiture in which the owner was entirely blameless). 
sidered the wrongdoer, regardless of the culpability of the owner. ${ }^{30}$ By placing his property in the hands of another, the owner ran the risk that forfeiture would attach to the object as a consequence of that person's "unlawful or wanton misconduct" that mvolved the object in a crime. ${ }^{31}$

\section{B. Modern Forfeiture Law in the United States}

Although forfeiture ${ }^{32}$ is still used in enforcement of the customs and revenue laws, ${ }^{33}$ its main use today is as a tool against crime, particularly the illegal drug trade. ${ }^{34}$ For example, several statutes now provide that on conviction for certain crimes, all assets involved in the crime are forfeit to the United States. ${ }^{35}$ Further, prosecutors may now use civil forfeiture as a powerful weapon against drug trafficking and money laundering. ${ }^{36}$

The first major expansion of the use of forfeiture came in 1970, when Congress revived criminal forfeiture by enacting the Organized Crime Control Act of $1970 .^{37}$ Title IX of this Act added chapter 96, Racketeer Influenced and Corrupt Organizations (RICO), ${ }^{38}$ to title 18 of the U.S. Code. Section 1963 of that title provides that on conviction of a substantive violation of RICO, a person is subject to penalties including forfeiture of assets acquired or maintained in violation of the statute and all interest in enterprises participating in the substantive violation..$^{39}$ The stated pur-

30. See Dobbins's Distillery, 96 U.S. at 401.

31. Id.

32. In this Section, unless otherwise indicated, "forfeiture" means civil or criminal forfeiture under any federal statute.

33. See, e.g., 19 U.S.C. $\& 1703$ (1988) (providing for forfeiture of ships intended for use in violation of customs or revenue laws).

34. See, e.g., H.R. REP. No. 427, 101st Cong., 2d Sess. 10 (1990) (calling asset forfeiture "one of the most important tools of law enforcement in the war on drugs"); see also United States v. 92 Buena Vista Ave., 113 S. Ct. 1126, 1145 (1993) (Kennedy, J., dissenting) (describing forfeiture as "the centerpiece of the Nation's drug enforcement laws").

35. See infra text accompanying notes 37-43.

36. See infra text accompanying notes $50-66$. Civil forfeiture is different from criminal forfeiture in two key respects. First, conviction is not a prerequisite for civil forfeiture. Second, the protections given accused persons in criminal proceedings do not apply. See infra text accompanying notes 68-74.

37. Pub. L. No. $91-452,84$ Stat. 922 (codified as amended in scattered sections of 18 U.S.C.).

38. 18 U.S.C. $\S \S 1961-1968$ (1988 \& Supp. IV 1992).

39. 18 U.S.C. \& 1963(a)(1)-(2) (1988 \& Supp. IV 1992). Modern criminal forfeiture differs from its older form in that persons are not necessarily deprived of all property on conviction. See supra text accompanying notes 17-18. 
pose of the provision was to weaken the influence of organized crime over legitimate business by returning enterprises to honest use as quickly as possible. ${ }^{40}$

Congress has since expanded the applicability of criminal forfeiture. RICO now provides for forfeiture of the proceeds of racketeering and reaches tainted assets even in the hands of others, except for bona fide purchasers for value. ${ }^{41}$ Other provisions for criminal forfeiture include the Continuing Criminal Enterprise statute (also known as the "Drug Kingpin statute") ${ }^{42}$ and the criminal inoney laundering statute. ${ }^{43}$

Revival of criminal forfeiture has been accompanied by expansion of the scope of civil forfeiture. As previously discussed, civil forfeiture originally applied to property involved in violations of the customs or revenue laws. ${ }^{44}$ Now, civil forfeiture is used to make crime less attractive by depriving criminals of the profits of crime. ${ }^{45}$ Moreover, civil forfeiture offers prosecutors many procedural advantages over criminal forfeiture. ${ }^{46}$ Most notably, a person may suffer civil forfeiture even though no one has been or will be convicted of or even charged with a crime. To seize an asset, the govenmient needs only to show probable cause to be-

40. 116 CONG. REC. 6709-10 (1970) (remarks of Rep. Poff).

41. Comprehensive Forfeiture Act of 1984, Pub. L. No. 98-473, ch. 3, sec. 302 , $\S$ 1963(a), (c), 98 Stat. 1837, 2040 (codified as amended at 18 U.S.C. $\S$ 1963(a), (c) (1988 \& Supp. IV 1992)).

42. 21 U.S.C. $\$ 848$ (1988). This provision was enacted a few months after the enactment of RICO as part of the Comprehensive Drug Abuse Prevention and Control Act of 1970, Pub. L. No. 91-513, \& 408, 84 Stat. 1236, 1265-66 (codified in scattered sections of 21 U.S.C.).

43. 18 U.S.C. \& 982 (1988 \& Supp. IV 1992).

44. See supra text accompanying notes 19-23.

45. S. REP. No. 225, supra note 6, reprinted in 1984 U.S.C.C.A.N. at 3374.

46. But see id. at 3379 (observing that despite civil forfeiture's relative advantages, the need to pursue civil actions duplicating criminal prosecution burdens prosecutors). A recent case from the Ninth Circuit has made the Double Jeopardy Clause another important consideration for prosecutors. In United States v. $\$ 405,089.23$ U.S. Currency, 33 F.3d 1210 (9th Cir. 1994), the court held that an action for civil forfeiture, when separate from a criminal prosecution, violated the Fifth Amendment's prohibition against putting a person in double jeopardy for the same crime. Id. at 1214. However, this decision conflicts with the holdings of two other circuits. See United States v. 18755 N. Bay Rd., 13 F.3d 1493, 1499 (11th Cir. 1994); United States v. Millan, 2 F.3d 17, 19 (2d Cir. 1993), cert. denied, 114 S. Ct. 922 (1994). Although prosecutors will now need to bring civil forfeiture actions as part of criminal prosecutions in some cases, the decision has no effect on civil forfeiture actions when prosecutors have no intention of ever charging the property owner with the criminal offense that is the basis for the forfeiture action. 
lieve that the asset bears the requisite relation to illegal activity. ${ }^{47}$ Once this is done, the property will be forfeit unless the owner, by a preponderance of the evidence, either shows that the connection does not exist or establishes a defense. ${ }^{48}$ Further, in a civil forfeiture proceeding, the burden of proof is on the owner to show innocence. ${ }^{49}$

Forfeiture is particularly inportant to the enforcement of drug laws. ${ }^{50}$ Section 881 of title 21 of the U.S. Code provides for civil forfeiture in drug cases. ${ }^{51}$ As originally enacted, ${ }^{52}$ section 881 was a traditional provision for statutory forfeiture. All contraband was forfeit to the United States, as was all real and personal property used or intended for use in the illegal use, production, distribution, import, or export of drugs. ${ }^{53}$

In 1978, Congress substantially expanded the scope of possible forfeitures; in addition to the property described above, property used to "facilitate" the drug trade became subject to forfeiture. ${ }^{54}$ The breadth of this term meant that prosecutors could seek forfeiture of assets related only indirectly to the drug trade..$^{55}$ The government could now also cause forfeiture of the proceeds of drug deahing. Later, the scope of section 881 was further expanded to include real property "used, or intended to be used[,] . . . to commit, or to facilitate" certain violations of federal drug laws. ${ }^{56}$

These changes also gave innocent owners the important new protection of an affirmative defense. As a result, no legal or equi-

47. E.g., Nnadi v. Richter, 976 F.2d 682, 686 (11th Cir. 1992).

48. See infra notes $68-74$ and accompanying text.

49. Id.

50. See supra note 34 .

51. 21 U.S.C. $\$ 881$ (1988 \& Supp. V 1993) provides for forfeiture of all illegal drugs, any vehicle used in the transportation, manufacture, or sale of drugs, any money or securities used in a drug offense, and any real property involved in a drug offense.

52. Comprehensive Drug Abuse Prevention and Control Act of 1970, Pub. L. No. 91-513, tit. II, § 511, 84 Stat. 1236, 1276 (current version at 21 U.S.C. § 881 (1988 \& Supp. V 1993)).

53. Id. \& 511(a) (current version at 21 U.S.C. \& 881(a) (1988 \& Supp. V 1993)).

54. Psychotropic Substances Act of 1978, Pub. L. No. 95-633, 92 Stat. 3768 (codified as amended at 21 U.S.C. $\& 881(\mathrm{a})(6)(1988))$.

55. See infra notes $102-04$ and accompanying text; see also United States v. 92 Buena Vista Ave., 113 S. Ct. 1126, 1133 (1993) (plurality opinion) (calling the amendment "an important expansion of government power").

56. Comprehensive Forfeiture Act of 1984, Pub. L. No. 98-473, tit. II, ch. III, § 306(a), 98 Stat. 2040, 2050 (codified at 21 U.S.C. \& 881(a)(7) (1988)). 
table interest in property is subject to civil forfeiture under section 881 if the owner establishes that he neither

knew [nor] consented to the fact that:

1. the property was furnished or intended to be furnished in exchange for a controlled substance in violation of law, 2. the property was proceeds traceable to such an illegal exchange, or

3. the property was used or intended to be used to facilitate any violation of Federal illicit drug laws. ${ }^{57}$

Although the Constitution probably requires some protection for innocent owners, ${ }^{58}$ it probably does not require as much as this statute provides. ${ }^{59}$ Nonetheless, the innocent owner defense is now incorporated into most federal forfeiture statutes. ${ }^{60}$

Another way to attack drug dealing and other crimes is to pursue directly the money these crimes generate. The drug trade generates huge amounts of currency that cannot easily be put into the stream of commerce. ${ }^{61}$ Recognizing that transactions involving large amounts of currency may be cause for suspicion, ${ }^{62}$ Congress

57. 124 CONG. REC. 34,672 (1978) (joint explanatory statement of Title III of the Psychotropic Substances Act). Although the natural reading of this statement indicates that knowledge or consent is an element to be proved by the government, the statute gives the owners of property the burden of proving lack of knowledge, lack of consent, or lack of willful blindness by a preponderance of the evidence. 21 U.S.C. $\S 881$ (a) (1988 \& Supp. V 1993).

58. See Austin v. United States, 113 S. Ct. 2801, 2809 (1993) ("In [no forfeiture case] did the Court apply the guilty-property fiction to justify forfeiture when the owner had done all that reasonably could be expected to prevent the unlawful use of his property."); Calero-Toledo v. Pearson Yacht Leasing Co., 416 U.S. 663, 688-89 (1974) (suggesting that forfeiture of truly innocent owner's property could "give rise to serious constitutional questions").

59. See Austin, $113 \mathrm{~S}$. Ct. at 2809-10 (observing that the Court has rejected lack of knowledge or lack of consent to illegal use as common law defenses to forfeiture); see also 18 U.S.C. \& 1963(c) (1988) (protecting transferee from forfeiture only when transferee establishes that he is a bona fide purchaser for value).

60. See, e.g., 18 U.S.C. § 981(a)(2) (1988) ("No property shall be forfeited under this section to the extent of the interest of an owner or lienholder by reason of any act or omission established by that owner or lienholder to have been committed without the knowledge of that owner or lienholder.").

61. "The importance of converting cash into a manageable physical form is illustrated by the case of Anthony Castelbuono. Castelbuono somewhat conspicuously brought $\$ 1,187,450$ in small bills to a casino. The cash had an estimated volume of 5.75 cubic feet and weighed 280 pounds." Sarah N. Welling, Smurfs, Money Laundering, and the Federal Criminal Law: The Crime of Structuring Transactions, 41 FLA. L. REV. 287, 291 (1989).

62. See H.R. REP. No. 975, 91st Cong., 2d Sess. 11-12 (1970), reprinted in 1970 
has required banks to report to the U.S. Treasury cash transactions involving more than $\$ 10,000 .^{63}$ To spend their gains without drawing attention to their activities, criminals must make the money appear to have had a legitimate source; doing so is called "laundering" the money. ${ }^{64}$ Since 1986 , money laundering itself has been a crime. ${ }^{65}$ Violators are subject to criminal fines, imprisonment, and criminal and civil forfeiture. ${ }^{66}$

Because profit is the motive for many crimes, the money laundering statutes described above try to fight crime by making it harder for crimmals to use the proceeds of their crimes. Provisions for civil and criminal forfeiture take a more direct approach and simply take property away from persons involved in crimes. By striking directly at the motive, civil forfeiture is a powerful weapon against crime, and the minimal protection for property owners in civil forfeiture cases greatly amplifies this power.

Civil forfeiture cases under any of these statutes follow a common pattern: the government will seize an asset, and then the

U.S.C.C.A.N. 4394, 4396-97.

63. 31 C.F.R. \& 103.22(a)(1) (1994). 31 U.S.C. \& 5313(a) (1988) requires banks to report transactions under circumstances to be prescribed by the Secretary of the Treasury. Under the current regulations, banks must report all transactions involving over $\$ 10,000$ in currency. Multiple transactions made in the same day are to be consolidated if the bank knows they are made on behalf of the same person. Because of attempts to evade this requirement, Congress subsequently enacted 31 U.S.C. $\S 5324$ (1988), making it a crime to cause a bank to fail to file a currency transaction report (CTR) or to structure a transaction to evade the reporting requirement. Sections 5313 and 5324 are often called the CTR statutes.

64. See, e.g., United States v. Cuevas, 847 F.2d 1417, 1419 n.2 (9th Cir. 1988), cert. denied, 489 U.S. 1012 (1989).

65. See 18 U.S.C. $\$ \S 1956-1957$ (1988). Section 1956(a)(1) prohibits certain transactions involving "proceeds of specified unlawful activity" when the transaction is intended to promote the crime or to hide the source of the money. Section 1957(a) makes it a crime knowingly to "engage[] or attempt[] to engage in a monetary transaction in criminally derived property that is of a value greater than $\$ 10,000$ and is derived from specified unlawful activity." Section 1957(f)(2) defines "criminally derived property" as "any property constituting, or derived from, proceeds obtained from a criminal offense." "Specified unlawful activity" is defined in 18 U.S.C. \& 1956(c)(7) as including mail and wire fraud, kidnapping, gambling, bribery, and drug crimes, among others.

66. Civil forfeiture of assets involved in violations of the money laundering statutes is provided for in 18 U.S.C. \& 981(a)(1) (1988 \& Supp. IV 1992). Section 981(a)(1)(A) subjects to forfeiture "[a]ny property, real or personal, involved in a transaction or attempted transaction in violation of [the money laundering or CTR statutes], or any property traceable to such property." Other parts of \& 981(a)(1) subject many other assets to forfeiture, including the proceeds of foreign drug crimes, $\$ 981(\mathrm{a})(1)(\mathrm{B})$, and of mail and wire fraud, $\S 981(a)(1)(D)(v)$-(vi). Subsection 981(a)(2) creates an affirmative defense for innocent owners. See supra notes 58-61 and accompanying text. 
owner will try to prevent forfeiture. ${ }^{67}$ The government may seize an asset when it has probable cause to believe that the asset is subject to forfeiture. ${ }^{68}$ Although the government must have probable cause before seizure, it usually does not have to show probable cause until afterwards. ${ }^{69}$ Following seizure, any person claiming an interest in the property is entitled to a hearing at which the government must show that it had probable cause to seize the asset; if the government fails to show this, the seizure is invalid and the property must be returned to its owner. ${ }^{70}$

67. See, e.g., United States v. All Funds Presently on Deposit, 832 F. Supp. 542 (E.D.N.Y. 1993).

68. In this context, "probable cause" means "reasonable ground for belief ... supported by less than prima facie proof but more than mere suspicion." United States v. Four Million, Two Hundred Fifty-Five Thousand, 762 F.2d 895, 903 (11th Cir. 1985) (citation omitted), cert. denied, 474 U.S. 1056 (1986). The statutes all state that to be subject to forfeiture, an asset must bear some connection to crime. See, e.g., 18 U.S.C. $\S 981$ (a)(1)(A) (1988 \& Supp. IV 1992) (subjecting to forfeiture all property "involved in" a violation of specified statutes). This Note addresses, in large part, the degree of connection required before property is subject to forfeiture, but logic dictates that there can be no probable cause to believe that property bears any relation to a statutory violation unless there is also probable cause to believe that the statute has been violated in the first place.

69. To commence in rem forfeiture proceedings, the government has several options. First, it can follow the procedure set forth in the Supplemental Rules for Certain Admiralty and Maritime Claims [hereinafter Supplemental Rules] and file a complaint with the clerk of the court having jurisdiction over the property. 18 U.S.C. $\S$ 981(b)(2) (Supp. IV 1992); 21 U.S.C. \& 881(b) (1988). Under Supplemental Rule C(3), the clerk must then issue a summons and warrant for the arrest of the property. Second, the property may be seized incident to a lawful arrest or search, or pursuant to a seizure warrant. 18 U.S.C. $\S 981(b)(2) ; 21$ U.S.C. $\S 881$ (b). Although the proceeding for a seizure warrant is ex parte, issuance requires a finding of probable cause by a federal magistrate. FED. $R$. CRIM. P. 41(c). Third, under 21 U.S.C. $\$ 881(b)(4)$, the Attorney General may seize assets when there is probable cause to believe that they are subject to civil forfeiture under the drug laws.

None of these procedures gives owners a hearing before their property is seized. Although the Supreme Court recently held that the lack of a hearing before seizure of real property generally violates the right to due process, United States v. James Daniel Good Real Property, 114 S. Ct. 492, 505 (1993), this principle probably does not extend to seizures of money. In Calero-Toledo v. Pearson Yacht Leasing Co., 416 U.S. 663, 679 (1974), the Court upheld seizure of a yacht prior to a hearing, reasoning that the property could easily be "removed to another jurisdiction, destroyed, or concealed, if advance warning of confiscation were given." Under this rationale, the government should be able to seize money before giving the owner a hearing because of the extreme ease and speed with which money moves by wire transfer and other means: See United States v. Daccarett, 6 F.3d 37, 49 (2d Cir. 1993) (rejecting Fourth Amendment challenge to warrantless seizure of bank account after finding that mobility of funds constitutes "exigent circumstances"), cert. denied, 114 S. Ct. 1294 (1994).

70. Marine Midland Bank, N.A. v. United States, 11 F.3d 1119, 1124-25 (2d Cir. 
Once the government seizes property and demonstrates probable cause for the seizure, the owner will forfeit the property without any further showing by the government unless he proves that the property is not subject to forfeiture. ${ }^{71}$ In contrast to the government's light burden of showing only probable cause to justify seizure, the claimant challenging forfeiture must make his showing by a preponderance of the evidence. ${ }^{72}$ The claimant also bears this same heavy burden under the innocent owner defense. ${ }^{73}$ Furthermore, although the government may use hearsay to establish probable cause, hearsay is inadinissible to show that property is not subject to forfeiture or to establish (or rebut) the innocent owner defense. ${ }^{74}$

1993); see 19 U.S.C. $\$ 1615$ (1988) (requiring that the government show probable cause before instituting forfeiture action). The procedures for civil forfeiture under the money laundering and drug statutes are generally those used for forfeiture under the customs laws. 18 U.S.C. § 981(d) (Supp. IV 1992); 21 U.S.C. \& 881(d) (1988). Under Supplemental Rule $E(4)(f)$, any person claiming an interest in seized property is entitled to a prompt hearing at which the government must show probable cause for the seizure. Moreover, a complaint under these rules must "state the circumstances from which the claim arises with such particularity that the ... claimant will be able, without moving for a more definite statement, to commence an investigation of the facts and to frame a responsive pleading." Supplemental Rule E(2)(a). In United States v. $\$ 39,000$ in Canadian Currency, 801 F.2d 1210, 1218-19 (10th Cir. 1986), the court held that the "drastic nature" of forfeiture required increased protection for claimants, and accordingly that ordinary notice pleading under the Federal Rules of Civil Procedure was inadequate under Supplemental Rule E(2)(a). Accord United States v. $\$ 38,000$ in U.S. Currency, 816 F.2d 1538, 1548 (11th Cir. 1986).

71. 19 U.S.C. $\& 1615$ (1988). This section is in the title of the U.S. Code that deals with customs laws. Because modern civil forfeiture grew out of the forfeiture provisions used to enforce the customs laws, see supra notes 19-28 and accompanying text, civil forfeiture statutes often specify the procedures in the customs statutes. See, e.g., 18 U.S.C. § 981(d); 21 U.S.C. § 881(d).

72. Daccarett, 6 F.3d at 57. This burden-shifting has survived constitutional challenge. See United States v. 228 Acres of Land and Dwelling, 916 F.2d 808, 814 (2d Cir. 1990) (forfeiture under 21 U.S.C. $\S 881(\mathrm{a})(6)$ (1988)), cert. denied, 498 U.S. 1091 (1991); United States v. One 1970 Pontiac GTO, 529 F.2d 65, 66 (9th Cir. 1976) (forfeiture under 21 U.S.C. \& 881(a)(4) (1988)).

73. See, e.g., United States v. 1988 Oldsmobile Cutlass Supreme, 983 F.2d 670, 674 (5th Cir. 1993) (civil forfeiture under 18 U.S.C. $\$$ 981(a)(1)(A) (1988 \& Supp. IV. 1992)); United States v. Real Property Located at Section 18, 976 F.2d 515, 520 (9th Cir. 1992) (forfeiture under 21 U.S.C. \& 881(a)(7) (1988)).

74. United States v. 6109 Grubb Rd., 886 F.2d 618, 621-22 (3d Cir. 1989); United States v. All Monies (\$477,048.62) in Account No. 90-3617-3, 754 F. Supp. 1467, 1471 (D. Haw. 1991). 


\section{SECTION 981 AND THE DEVELOPMENT OF THE FACILITATION THEORY}

The facilitation theory arose as a justification under the money laundering forfeiture statute ${ }^{75}$ for seizing untainted funds that had been mixed with forfeitable proceeds of money laundering. This Part explains the facilitation theory and reviews the seminal cases in its development. It then surveys subsequent cases to gauge the influence of the theory.

\section{A. The Development of the Facilitation Theory}

The facilitation theory seems simple. Under 18 U.S.C. $\S 981(\mathrm{a})(1)(\mathrm{A})$, property "involved in" money laundering transactions is subject to forfeiture. Property that facilitates money laundering is considered to be "involved in" money laundering. Under a broad definition of facilitation, untainted money that mixes with the proceeds of crime facilitates money laundering by making the tainted money look innocent. Thus, by facilitating money laundering, the untainted money becomes involved in money laundering and is subject to forfeiture.

The first case to apply this theory was United States $v$. All Monies $(\$ 477,048.62)$ in Account No. 90-3617-3. ${ }^{76}$ This case was one of several stemming from the criminal investigation of a Peruvian money laundering and drug organization. The claimant was the owner of a Peruvian money exchange, or cambio, ${ }^{77}$ whose bank accounts in New York were seized as subject to forfeiture

75. 18 U.S.C. $\& 981$ (1988 \& Supp. IV 1992). Although referred to in this Note as "the money laundering forfeiture statute," $\S 981$ subjects to forfeiture property that is involved in numerous different crimes, many of which are unrelated to money laundering. See supra note 66.

76. 754 F. Supp. 1467 (D. Haw. 1991).

77. A cambio is a kind of money exchange house in Latin America. Cambios operate independently of governmental foreign exchange, trading dollars for local currency and vice versa. They also maintain accounts in dollars in the United States for clients who, for reasons varying from concern over personal safety to tax evasion, do not want to keep assets in domestic banks. See generally Alan S. Fine, Of Forfeiture, Facilitation and Foreign Innocent Owners: Is a Bank Account Containing Parallel Market Funds Fair Game?, 16 NovA L. REV. 1125, 1131-32 (1992) (describing the function of cambios).

Considering the Latin American source of many drugs, it is not surprising that many forfeiture cases have involved cambios. See, e.g., United States v. $\$ 173,081.04$ in U.S. Currency, 835 F.2d 1141 (5th Cir.), cert. denied, 488 U.S. 850 (1988); United States v. All Funds Presently on Deposit, 832 F. Supp. 542 (E.D.N.Y. 1993). 
under 18 U.S.C. $\S 981(\mathrm{a})(1)(\mathrm{A})-(\mathrm{B})$ and 21 U.S.C. $\S 881(\mathrm{a})(6){ }^{78}$ The claimant conceded that probable cause existed to believe that some of the funds in the seized account were proceeds of money laundering, ${ }^{79}$ and the government conceded that most of the claimant's transactions were legitimate. ${ }^{80}$ The court held that the legitimate money provided a "cover" for transfers of the tainted money and was thus subject to forfeiture for "facilitat[ing] the illegal activity." ${ }^{\text {"1 }}$

The scope of the theory was developed further in United States v. Certain Funds on Deposit in Account No. 01-0-71417 $7^{82}$ and United States v. Certain Accounts. ${ }^{83}$ Certain Funds involved fraud by the owners of a federal credit union. The government sought forfeiture of five bank accounts, alleging that the funds they contained either were the proceeds of a crime against a financial institution ${ }^{84}$ or were, under the facilitation theory, involved in money laundering transactions. ${ }^{85}$ The court agreed and held the entire balances to be subject to forfeiture under the facilitation theory, adding that even if only part of the legitimate money facilitated the offense, the entire sum was subject to forfeiture. ${ }^{86}$

In Certain Accounts, money launderers had employed "smurfs" to buy money orders below the reporting threshold of 31 U.S.C. $\S 5322 .{ }^{87}$ Some of the money orders were then deposited in bank accounts ("direct recipient accounts") in New York and Florida. ${ }^{88}$ The government sought forfeiture of the direct accounts under the

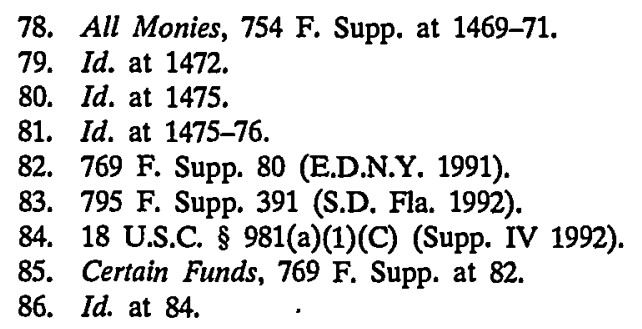

87. Certain Accounts, 795 F. Supp. at 392-93. When Congress first required banks to report large cash transactions, money launderers tried to avoid the regulations by breaking large amounts of currency into portions below the $\$ 10,000$ threshold and having subordinates (known as "smurfs," after the small, blue cartoon characters) make the deposits. See generally Welling, supra note 62 (describing the development of smurfing and the legislative response to it). Certain Accounts steinmed from the arrest of a sinurf who tried to assault a customs agent with a machine gun. When arrested, the sinurf had receipts for approximately one million dollars im money orders. Certain Accounts, 795 F. Supp. at 393.

88. Certain Accounts, 795 F. Supp. at 393. 
facilitation theory ${ }^{89}$ However, checks drawn on the direct accounts had been deposited into other accounts ("indirect recipient accounts"), and the government sought forfeiture of the entire balances of these accounts, too. ${ }^{90}$ The court followed All Monies to the extent of allowing forfeiture of the direct accounts, but held that the mere tracing of checks into an indirect account was insufficient to justify forfeiture of the entire balance. ${ }^{91}$ Asserting that forfeitability was not analogous to contamination radiating outwards from an account like a "contagious disease," the court rejected the extension of the facilitation theory with regard to the mdirect accounts, saying that probable cause was too "attenuated." 92

\section{B. The Argument Behind the Facilitation Theory}

The simple statement of the facilitation theory obscures two interpretive leaps. First, one must construe section 981 to reach facilitating property, even though it nowhere contains the word "facihtate." Second, one must conclude that the mere commingling of funds amounts to such facilitation. ${ }^{94}$ Neither one of these leaps is obvious. Moreover, even after the word "facilitate" is read into the statute. its meaning is hardly self-evident. For these reasons, considerable uncertainty has accompanied application of the theory. ${ }^{95}$

The conclusion that the statute covers property that "facilitates" money laundering is usually supported by reference to the legislative history of section 981. Section 981(a)(1)(A) originally subjected to forfeiture only the direct or indirect "gross receipts" of money laundering," but the statute was amended in 1988 to

89. Id.

90. Id.

91. Id. at 397-98.

92. Id. at 398. The court further noted that the broader theory could be limited only by the government's imagination. Id.

93. United States v. All Monies (\$477,048.62) in Account No. 90-3617-3, 754 F. Supp. 1467, 1472 (D. Haw. 1991).

94. Id. at $1475-76$.

95. Compare United States v. $\$ 448,342.85$, 969 F.2d 474, 476-77 (7th Cir. 1992) (rejecting facilitation theory under 18 U.S.C. \& 981) with United States v. Certain Funds on Deposit in Account No. 01-0-71417, 769 F. Supp. 80, 84 (E.D.N.Y. 1991) (holding entire balances in accounts subject to forfeiture even if only part of the money facilitated money laundering) and Certain Accounts, 795 F. Supp. at 397-98 (holding subject to forfeiture only accounts into which tainted funds were directly deposited).

96. Money Laundering Control Act of 1986, Pub. L. No. 99-570, tit. I, subtit. H, 
reach all property "involved in" a violation of the inoney laundering or currency transaction reporting statutes. ${ }^{97}$ The cases applying the facilitation theory cite the Senate Judiciary Committee's analysis of the amendment, ${ }^{98}$ which states that "the term 'property involved' is intended to include the money or other property being laundered (the corpus), any commissions or fees paid to the launderer, and any property used to facilitate the laundering offense." $" 99$

Having construed section 981 to reach facilitating property, courts have then focused on the meaning of "facilitate" instead of the language of the statute. ${ }^{100}$ Because courts have defined "facilitation" broadly, prosecutors have argued successfully that mixing clean and dirty money facilitates money laundering. Facilitation has been identified as "making the prohibited conduct less difficult or 'inore or less free from obstruction or hindrance.'"101 This definition came from cases interpreting the drug forfeiture statute, ${ }^{102}$ which expressly provides for forfeiture of facilitating property. ${ }^{103}$

In its original context, this definition has caused the forfeiture of assets related only indirectly to crime. For example, in United States v. Rivera, ${ }^{104}$ a case involving criminal forfeiture of property facilitating drug trafficking under 21 U.S.C. $\S 853,{ }^{105}$ the court

§ 1366(a), 100 Stat. $3207-18,3207-35$ (codified at 18 U.S.C. $\S 981$ (1988 \& Supp. IV 1992)).

97. Pub. L. No. 100-690, tit. VI, $\S 6463(a)(1), 102$ Stat. 4374 (18 U.S.C. $\S 981(\mathrm{a})(1)(\mathrm{A})(1988))$.

98. See, e.g., Certain Accounts, 795 F. Supp. at $396^{\circ}$ n.10; All Monies, 754 F. Supp. at 1473; United States v. Certain Funds on Deposit in Account No. 01-0-71417, 769 F. Supp. 80, 84 (E.D.N.Y. 1991) (citing All Monies, 754 F. Supp. at 1473).

99. 134 CONG. REC. S17, 365 (Nov. 10, 1988).

100. See, e.g., United States v. Eleven Vehicles, 836 F. Supp. 1147, 1153 (E.D. Pa. 1993); All Monies, 754 F. Supp. at 1473.

101. United States v. 3639-2nd St., N.E., 869 F.2d 1093, 1096 (8th Cir. 1989); see also United States v. Schifferli, 895 F.2d 987, 990 (4th Cir. 1990).

102. 21 U.S.C. $\S 881$ (1988 \& Supp. V 1993).

103. See, e.g., Schifferli, 895 F.2d at 990; 3639-2nd St., N.E., 869 F.2d at 1096.

104. 884 F.2d 544 (11th Cir: 1989), cert. denied, 494 U.S. 1018 (1990).

105. This statute is the criminal counterpart to 21 U.S.C. $\$ 881$, the civil drug forfeiture statute. It provides that when someone is convicted of a drug felony, that person forfeits, among other things, any "property used, or intended to be used, in any manner or part, to commit, or to facilitate the commission of, such violation." 21 U.S.C. $\S 853(\mathrm{a})(2)$ (1988). Because of the common context, the interpretation of the word "facilitate" under 21 U.S.C. \& 853 is relevant to the scope of the facilitation theory under 18 U.S.C. $\S 981$. 
upheld a jury verdict of forfeiture of twenty-seven horses on the ground that the claimant's horse business provided a "cover" for drug dealing. ${ }^{106}$ The court noted that the claimant had used terins froin the horse-breeding business as code words in arranging the distribution of heroin. Interestingly, the jury found that the ranch where the defendant arranged the drug deals was not subject to forfeiture. ${ }^{107}$ A more extreme example is United States $v$. One Lot Jewelry, in which the court held that the claimant's jewelry had facilitated drug dealing by "enhanc[ing] his status in the drug community." 108

Substantial litigation has taken place over the degree of connection required between the property sought to be forfeited and the underlying criminal offense. ${ }^{109}$ Some courts require that the government establish probable cause to believe that the property has a "substantial connection" to one of the crimes defined in section 881 for the seizure to stand. ${ }^{110}$ Other courts have adopted a looser test, requiring only that the government demonstrate a nexus between the seized property and illegal drug activity. ${ }^{111}$ It has been suggested that the distinction is more semantic than substantive, with the real issue being whether facilitation, as defined above, has occurred. ${ }^{112}$ The cases do agree that to be subject to forfeiture, "the property must have more than an incidental or fortuitous connection to criminal activity."113

Finally, although the connection between the illegal activity and the property needs to be more than de minimis, the amount of illegal activity generally does not. ${ }^{114}$ This rule may change in the future, however, considering the Supreme Court's recent deci-

106. Rivera, 884 F.2d at 546 .

107. Id.

108. 749 F. Supp. 118, 123 (W.D.N.C. 1990).

109. See United States v. 42450 Highway 441,920 F.2d 900, 902 (11th Cir. 1991).

110. See, e.g., United States v. Schifferli, 895 F.2d 987, 989 (4th Cir. 1990); United States v. One 1990 Porsche Carrera, 807 F. Supp. 371, 373 (D. Md. 1992).

111. E.g., United States v. Daccarett, 6 F.3d 37, 55 (2d Cir. 1993).

112. 42450 Highway 441,920 F.2d at $902-03$.

113. Id. at 903; Schifferli, 895 F.2d at 990 .

114. United States v. 3639-2nd St., 869 F.2d 1093, 1096 (8th Cir. 1989) (holding relative smallness of amount of cocaine sold to be irrelevant to issue of forfeiture of home); see also Calero-Toledo v. Pearson Yacht Leasing Co., 416 U.S. 663 (1974) (upholding forfeiture of yacht under Puerto Rican statute when one marijuana cigarette was found on board). 
sion in Austin v. United States. ${ }^{115}$ In Austin, the Court held that civil forfeiture was punitive in part and thus subject to the Eighth Amendment's Excessive Fines Clause. ${ }^{116}$ However, the Court explicitly declined to establish a test for identifying unconstitutionally excessive forfeitures. ${ }^{117}$ Concurring im the judgment, Justice Scalia suggested that the Constitution requires only that the asset subject to forfeiture bear a sufficiently close relationship to the underlying offense. ${ }^{118}$ If Justice Scalia's view is correct, the definition of "facilitation" nay be critical to establishing the constitutional limits to forfeiture.

The drug cases developed a very broad idea of the kind of facilitation that would subject property to forfeiture. When "facilitation" was read into the money laundering forfeiture statute, the broad notion came with it. The result was to give prosecutors expansive authority to seize assets and seek forfeiture.

\section{The Influence of Facilitation Theory Under 18 U.S.C. § 981}

Prosecutors have enjoyed mixed success in achieving forfeiture of bank accounts under section 981 under the facilitation theory. ${ }^{119}$ On the one liand, several courts liave applied the theory to justify forfeiture of the entire balance of bank accounts containing proceeds of violations of the money laundering statutes, 18 U.S.C. $\S 1956$ and 18 U.S.C. $\S 1957 . .^{120}$ On the other hand, nost attempts to apply the theory to accounts containing proceeds of other offenses have failed, and some courts have rejected the theory altogether. ${ }^{121}$

Some courts have adopted the facilitation theory when the evidence has suggested that the mixture of funds was purposeful. For example, in United States v. Contents of Account Numbers 208-06070 and 208-06068-1-2, the U.S. District Court for the Soutliern District of New York found that the number of bank accounts opened during the defendant's illegal scheme was evidence that the accounts were intended to disguise the proceeds of the

\footnotetext{
115. 113 S. Ct. 2801 (1993).

116. Id. at 2812 .

117. Id.

118. Id. (Scalia, J., concurring).

119. All the forfeiture cases in this Section involve actions under 18 U.S.C. § 981(a)(1)(A) (1988 \& Supp. IV 1992).

120. See infra notes $122-25$ and accompanying text.

121. See infra notes $126-43$ and accompanying text.
} 
scheme. ${ }^{122}$ Because "[a]ny legitimate money in the Six Accounts would serve to further disguise the source of the illegitimate funds and to make the proceeds of the ... scheme more difficult to trace," the court held that all funds in the accounts were forfeitable as facilitating property. ${ }^{123}$ Similarly, in United States $v$. Tencer, the trial court upheld the seizure of all funds in certam bank accounts, ${ }^{124}$ concluding that the tainted money had been mixed with legitimate funds "for the purpose of concealing the defendant's alleged criminal activities."125

Other courts, while agreeing with the facilitation theory in the abstract, have denied forfeiture, saying either that the property involved was too remote from the underlying crime or that the theory did not apply to the substantive offense in the case. For example, in United States v. All Funds on Deposit, ${ }^{126}$ the district court held that violations of the currency transaction reporting and anti-smurfing statutes ${ }^{127}$ were not the sort of crimes that could be facilitated by deposits of untainted money in a bank account. The government established probable cause that soine deposits had illegally been structured to avoid the reporting requirements, and those deposits were subject to forfeiture under section $981 .^{128} \mathrm{In}$ denyimg forfeiture of the rest of the money, the court explained that it could not understand how the legitimate money already in the account facilitated the other, illegal deposits. ${ }^{129}$ In another case, Marine Midland Bank, N.A v. United States, the district court held that the entire balance of an interbank account was not subject to forfeiture when the government made "no allegations that such account is controlled, nominally or effectively, by anyone with

122. 847 F. Supp. 329, 335 (S.D.N.Y. 1994).

123. Id.

124. Crim. A. No. 92-570, 1993 WL 310527, at *3-*4 (E.D. La. Aug. 11, 1993) (involving forfeiture under $\S 981$ and its criminal counterpart, 18 U.S.C. $\S 982$ ). The court cited Certain Accounts, Certain Funds, and All Monies as support for its conclusion.

125. Tencer, 1993 WL 310527 at $* 5$ n.15.

126. 804 F. Supp. 444,447 (E.D.N.Y. 1992).

127. 31 U.S.C. $\S \S 5313,5324$ (1988 \& Supp. V 1993).

128. All Funds on Deposit, 804 F. Supp. at 446.

129. Id. at 447. The court called the theory "completely logical" in the context of money laundering, but the government had predicated forfeiture under 18 U.S.C. $\S 981$ (1988 \& Supp. IV 1992) on violation of the CTR statutes, not money laundering. Id.; accord United States v. Account No. 50-2830-2, 857 F. Supp. 1534, 1540 (M.D. Ala. 1994) (holding that deposits in violation of CTR statute do not subject legitimate money in account to forfeiture under 18 U.S.C. \& 981). Contra United States v. Certain Accounts, 795 F. Supp. 391, 397 (S.D. Fla. 1992). 
even a partially illegal purpose."130 Accordingly, the court held that only the funds traceable to illegal activity were subject to forfeiture under section $981 .{ }^{131}$

Finally, some courts have simply rejected facilitation theory as a ground for forfeiture of otherwise untainted money. In United States $v . \$ 448,342.85,{ }^{132}$ prosecutors sought forfeiture of the entire balances of bank accounts that contained both laundered proceeds of fraud and untainted money. Judge Easterbrook specifically disapproved of Certain Funds and All Monies, asserting that "the presence of one illegal dollar in an account does not taint the rest-as if the dollar obtained from fraud were like a drop of ink falling into a glass of water." 133 Judge Easterbrook described an account as "a routing device like the address of a building" and said that to hold that the account facilitated laundering of money deposited into it was unacceptable because it turned the account into a deodand. ${ }^{134}$

Statutory interpretation was the basis for rejecting facilitation theory in United States v. All Funds Presently on Deposit. ${ }^{135}$ The U.S. District Court for the Eastern District of New York found the theory suspect because the word "facilitate" appeared in section 881 (a)(6) but not in the later-enacted section 981(a)(1)(A). ${ }^{136}$ The basis for the decision, though, was that the court beheved facilitation theory to be incompatible with 18 U.S.C. $\S 984$. That section made it unnecessary for prosecutors to identify precisely fungible property subject to forfeiture, instead allowing

130. Nos. 93 Civ. 0307, 0357, 1993 WL 158542, *7-*8 (S.D.N.Y. May 11, 1993), affd in part, remanded in part, 11 F.3d 1119 (2d Cir. 1993). The case involved the seizure of an account used between banks to clear checks. The Panama branch of a British bank holding company would collect, sort, and microfilm checks and money orders, and then forward them for payment to the institutions on which they were drawn. Id. at $* 1$. Checks drawn on banks in the United States were sent to the bank's account at Marine Midland Bank in New York. That account, called an interbank account, was the subject of the forfeiture action. Id. The complaint alleged that "a substantial majority of the Postal money orders negotiated through the defendant-in-rem account were in $\$ 500, \$ 600$, and $\$ 700$ denominations, 'were purchased over consecutive days and bore accounting symbols used by Colombian drug cartels.' " Id. at *2.

131. Id. at *8.

132. 969 F.2d 474, 475-76 (7th Cir. 1992).

133. Id. at 476.

134. Id.; see supra text accompanying notes 13-15; supra note 25 and accompanying text.

135. 832 F. Supp. 542 (E.D.N.Y. 1993).

136. Id. at 559 . 
them to seize identical property found in the same place where forfeitable property had been. It was enacted in $1988,{ }^{137}$ in response to cases like United States v. Banco Cafetero Panama, in which the trial court faced coinplicated problems in tracing drug proceeds. ${ }^{138}$

The court in All Funds Presently on Deposit concluded froin the legislative history of section 984 that Congress did not believe that comminglimg was an independent basis for forfeiture. ${ }^{139}$ The court also held that the facilitation theory would gut the one-year statute of limitations provided in section $984,{ }^{140}$ because every deposit would become an independent wrongful act, resetting the statute of limitations for forfeiture. ${ }^{141}$ The court found further

137. Annunzio-Wylie Anti-Money Laundering Act, Pub. L. No. 102-550, tit. XV, $\S 1522$, 106 Stat. 4044-63 (1988).

138. 797 F.2d 1154 (2d Cir. 1986). Banco Cafetero involved tracing proceeds of drug dealing through bank accounts. The court held that when drug money was deposited in a bank account and then withdrawals and deposits were made, only the lowest intermediate account balance after the deposit of drug money could be considered proceeds of drug dealing (the "drugs-in last-out" rule). Id. at 1159-60 \& n.5. This rule encourages money launderers to put money in accounts with wildly fluctuating balances: after the balance dipped to zero, all subsequent deposits would be immune from forfeiture, but because the money would be quickly replenished, the funds would still be available for withdrawal after the account had "zeroed out."

139. All Funds Presently on Deposit, 832 F. Supp. at 560. The court cited a section of the legislative history of 18 U.S.C. $\S 984$ (Supp. IV 1992) to the effect that prosecutors had problems tracing drug proceeds because it was impossible to identify dirty money after it had been mixed with other funds. All Funds Presently on Deposit, 832 F. Supp. at 560 . The court reasoned that there would be no need to identify specific property subject to forfeiture if the entire mixture were forfeitable under a facilitation theory. But cf. Russello v. United States, 464 U.S. 16, 26 (1983) ("[I]t is well settled that 'the views of a subsequent Congress form a hazardous basis for inferring the intent of an earlier one.'" (citations omitted)).

140. 18 U.S.C. \& 984(c) (Supp. IV 1992).

141. All Funds Presently on Deposit, 832 F. Supp. at 561. The example given by the court is helpful:

Assume that on January $1,1995, \$ 100$ in drug money and $\$ 500$ in legitimate money-money that the government has no basis for alleging as being derived from specified unlawful activity-is deposited into an account. On February 1,1995, the account balance dips to zero. On March 1, 1995, the account climbs to $\$ 1,000$; once again, the government has no basis for believing that the most recently deposited funds are the proceeds of some specified unlawful activity. The government seeks to forfeit the account on March 2, 1995. If Banco Cafetero were the governing law, none of the money would be subject to forfeiture because the unlawful activity occurred before the account "zeroed out." Under Section 984, which allows the government one year in which to forfeit fungible property, $\$ 100$ is subject to forfeiture as a substitute for the fungible property that was actually involved in the specified unlawful activity. Facilitation theory would allow seizure of the legitimate funds which were commingled with the tainted funds; although it is not exactly clear whether the amount subject to forfeiture would be $\$ 900$ (the balance now in the account) or $\$ 500$ (the balance 
support in United States v. $\$ 448,342.85^{142}$ for its conclusion that these difficulties were fatal to the facilitation theory. ${ }^{143}$

\section{INTENT AND THE LIMITS OF FACILITATION THEORY}

Congress has expressed a clear desire to attack drug dealing and inoney laundering, and facilitation theory gives prosecutors a powerful weapon in the fight. However, the broad facilitation theory casts an extrennely wide net, and when coupled with the looseness of the procedural safeguards that accompany civil forfeiture, creates opportunities for serious abuses. Innocent third parties can suffer substantial deprivations of property, and criminals might suffer automatic deprivations of all property. Further, if commingling alone is grounds for forfeiture, then facilitation theory rests on the fiction of the property as wrongdoer, a fiction that has never been accepted in the United States. ${ }^{144}$

Facilitation theory can be made both coherent and fairer by focusing on the intent of the possessor of the inoney. Although the intent requirement is implicit in many existing cases, making it explicit would provide greater protection for innocent persons from the burdens of seizure and of defending against forfeiture. Because many courts seem inplicitly to have looked to intent in some way, inoreover, requiring a showing of intent would not greatly increase the burden on prosecutors. By using intent as a standard, courts would also prevent the facilitation theory from depriving criminals of all property.

originally deposited in the account), there is a strong argument that if forfeiture is premised on the commingling and hiding of illegitimate funds, the entire balance currently in the account would be forfeit.

Now assume that the government did not seize the account on March 2, 1995 but instead waited until January 2,1996 . Clearly, with respect to the $\$ 100$ and the $\$ 500$ deposited into the account on January 1,1995 the one-year period has expired; however, since $\$ 1000$ replaced the funds in the account on March 1,1995 , the government is still within the one-year statute of limitations for forId. feiture of that "facilitating property."

142. 969 F.2d 474, 476-77 (7th Cir. 1992).

143. All Funds, 832 F. Supp. at 561-62.

144. Despite the statements of some courts that seem to indicate the contrary, see supra notes 29-30 and accompanying text, the doctrine of inanimate objects as wrongdoers, or deodands, has never been a part of American law. See supra note 25. The Supreme Court has said that to the extent that property has been regarded as a wrongdoer, it has always been as a proxy for the owner's conduct. Austin v. United States, $113 \mathrm{~S}$. Ct. 2801, 2809 (1993). 


\section{A. The Dangers of the Broad Facilitation Theory}

The problem with a facilitation theory that does not consider intent is that such a theory has no limits. According to the prosecutors who seize money under this theory, dirty money taints the clean money with which it is mixed. Every check written on an account containing dirty money is itself dirty money, and taints any account into which it is deposited, and so on. ${ }^{145}$ Shortly, the taint metastasizes to all of a person's assets, ${ }^{146}$ and probably to the assets of those who have dealt with the crimmal. ${ }^{147}$ Although many courts have refused to take this theory to its logical extreme, ${ }^{148}$ they have not announced a limiting principle. Absent such a principle, the desire for logical consistency is a force tending towards broad application of the theory.

Admittedly, Congress intends to treat money launderers severely and to strip the drug trade of the imcentive of profit. The broad facilitation theory helps prosecutors seize assets that might be unreachable under a narrower interpretation of the statute. ${ }^{149}$ Further, by increasing the scope of forfeiture, the broad facilitation theory increases its deterrent effect.

The effects of the broad facilitation theory, however, do not fall solely on money launderers and those who deal with them. The theory also exposes to seizure many assets in the hands of those who cannot reasonably be expected to do anything about drug deahing or money laundering. If mere mixture of clean and dirty money amounts to facilitation of money laundering, probable cause exists to believe that virtually any asset has facilitated money laundering. The effect is to give prosecutors open-ended discretion to seize assets almost at will. This power is even more trou-

145. See United States v. $\$ 448,342.85,969$ F.2d 474, 476 (7th Cir. 1992) (reasoning that under facilitation theory, tainted money in an account becomes like ink contaminating water into which it is dropped); United States v. Certain Accounts, 795 F. Supp. 391, 398 (S.D. Fla. 1992) (comparing tainted money under facilitation theory to a contagious disease).

146. See Certain Accounts, 795 F. Supp. at 398.

147. See id. at 398 n.12. ("If a direct accountholder were to write a check to pay bills from Florida Power \& Light, or the University of Florida, or made unsolicited donations to members of the Miami police force, each of these "claimants" accounts would be subject to arrest and forfeiture.").

148. E.g., id. at 398.

149. United States v. Eleven Vehicles, 836 F. Supp. 1147, 1154-55 (E.D. Pa. 1993). 
bling considering that proceeds of forfeiture go into the budgets of law enforcement agencies. ${ }^{150}$

An expansive interpretation of "facilitation" is even more dangerous under the money laundering forfeiture statute than it is under the drug trafficking statute ${ }^{151}$ for just this reason. An asset may be subject to forfeiture for having been involved in a drug deal, but there is no plausible claim that everything done with that asset following the illegal transaction necessarily facilitated that transaction. A car, for example, may be subject to forfeiture for having once transported drugs, but no one would assert that other assets would become tainted simply by putting them in the trunk one week after the drug deal. In the case of money laundering, though, every transaction involving dirty money adds another step that law enforcement agents must trace to connect that money to a crime. The broad facilitation theory claims that every transaction is thus an independent act of facilitation, tainting all other assets involved in the transaction.

Ultimately, because of the ease with which taint spreads from asset to asset, the broad facilitation theory effectively would work a revival of forfeiture of estate, whereby felons and traitors were anciently divested of the right to own property. ${ }^{152}$ The reason is that the innocent owner defense ${ }^{153}$ is not available to those with

150. See 28 U.S.C. $\S 524$ (c) (Supp. V 1993) (creating special fund, containing proceeds of forfeiture, available for law enforcement); see also United States v. James Daniel Good Real Property, 114 S. Ct. 492 (1993), in which the Court noted,

The extent of the Government's financial stake in drug forfeiture is ap-

parent from a 1990 memo, in which the Attorney General urged United States

Attorneys to increase the volume of forfeitures in order to meet the Depart-

ment of Justice's annual budget target:

"We must significantly increase production to reach our budget target.

....

... Failure to achieve the $\$ 470$ million projection would expose the Department's forfeiture program to criticism and undermine confidence in our budget projections. Every effort must be made to increase forfeiture income during the remaining three months of [fiscal year] 1990."

Id. at 502 n.2 (quoting Executive Office for United States Attorneys, U.S. Dep't of Justice, 38 U.S. ATT'YS BULL. 180 (1990) (alteration in original)). This sort of "reinvestment" has been described as giving "an entirely new meaning to the expression, "you eat what you kill.' " Fine, supra note 77, at 1127 n.8.

151. 21 U.S.C. \& 881 (1988 \& Supp. V 1993).

152. See supra text accompanying notes 17-18; see also United States v. Pole No. 3172, 852 F.2d 636, 639-40 (1st Cir. 1988) (rejecting forfeiture of entire interest in property when mortgage payments made with proceeds of drug trade because 21 U.S.C. \& 881 ought not to be construed to deny accused drug dealers the right to own property).

153. 18 U.S.C. \& 981(a)(2) (1988). 
knowledge of the underlying illegal activity. ${ }^{154}$ If every asset a money launderer owns is tainted by the facilitation theory, but he is deprived of all defenses, then he has in effect been denied the right to own property. However, Congress explicitly abolished forfeiture of estate in $1790 ; ;^{155}$ courts should not lightly read its revival into current forfeiture statutes.

For those not engaged in lawbreaking, the innocent owner defense provides some protection from forfeiture but not from seizure. ${ }^{156}$ Innocent owners could thus be deprived of the use of property until the opportunity to demonstrate innocence arose, possibly incurring substantial harm. ${ }^{157}$ The problem is even worse

154. United States v. Eleven Vehicles, 836 F. Supp. 1147, 1160 (E.D. Pa. 1993) (citing United States v. 717 S. Woodward St., 2 F.3d 529, 533 (3d Cir. 1993)); see also United States v. 21090 Boulder Circle, No. 92-1589, 1993 WL 432376, at *3-*4 (6th Cir. Oct. 25, 1993) (upholding forfeiture of house based on facilitation theory, when owner knew of structuring violation involving money used to purchase house).

155. See supra notes $26-27$ and accompanying text.

156. See supra note 57 . The protection is limited, however, because of the shifted burden of proof. See supra note 57.

The cases assume that the defense is available for owners of facilitating funds. See, e.g., United States v. All Funds Presently on Deposit, 832 F. Supp. 542, 562 n.16 (E.D.N.Y. 1993). However, this may be inconsistent with the notion that commingling of funds is itself a wrongful act of facilitation. To seize property, the government must have probable cause to believe that it is subject to forfeiture. See supra text accompanying notes $68-70$. If probable cause is established as to facilitating property merely by showing that it was found in the same place, two possible implications arise: either the property is subject to forfeiture regardless of any person's culpability, in which case an innocent owner defense makes no sense, or the mere fact of admixture provides probable cause to believe that someone was culpable, and the burden of proof slifts to the owner to show that it was not he. If the law of the United States does not recognize deodands, CaleroToledo v. Pearson Yacht Leasing Co., 416 U.S. 663, 682 (1974), the second alternative must be correct.

157. The harm could be simply financial, such as the loss of the opportunity to earn interest on seized money, but may be as severe as the loss of one's home. For examples of large cash seizures in which only small amounts were connected to crimes, see All Funds Presently on Deposit, 832 F. Supp. at 563-64 (claimant deprived of use of $\$ 1,200,000$ but probable cause shown only as to $\$ 75,000$ ); Marine Midland Bank, N.A. v. United States, Nos. 93 Civ. 0307, 0357, 1993 WL 158542, at *3 (S.D.N.Y. May 11, 1993), affd in part, remanded in part, 11 F.3d 1119 (2d. Cir. 1993). In United States v. Certain Accounts, 795 F. Supp. 391 (S.D. Fla. 1992), the court observed,

There exists a real possibility that unknowing and factually innocent accountholders who have received an allegedly tainted deposit may be deprived of the use of the funds until such time as they can assert the innocent owner defense. ... [T] he action may proceed for months or perhaps years with no sliowing that the accountholder had any knowledge of the money laundering.

Id. at 395. The government argued that in addition to the innocent owner defense, prosecutorial discretion in bringing suit protected owners, $I d$. at $398 \mathrm{n} .12$. The court held that this protection was inadequate. Id. at 398. 
because the government bears a very light burden in civil forfeiture cases. ${ }^{158}$ In contrast, following seizure, the owner has the burden of proving a negative: he must prove either that the property was not involved in money laundering ${ }^{159}$ or that he did not know of or consent to any criminal activity. ${ }^{160}$

The broad facilitation theory thus gives prosecutors enormous power to impose costs and threaten extensive forfeiture, based only on probable cause. Further, once probable cause is established, the government can seize assets and sit on them, investigating the underlying criminal allegations later. ${ }^{161}$ These problems are compounded by the difficulty of challenging a proposed forfeiture under an uncertain standard. ${ }^{162}$ Considering both the conflict of interest faced by prosecutors who stand to benefit from forfeiture and the potential for abuse against unpopular defendants, the broad facilitation theory is too dangerous.

\section{B. Intent as the Determinative Element}

Despite the foregoing problems, the fact remaims that money from legitimate sources can be used in laundering dirty money. ${ }^{163}$ For example, in All Monies, the case in which the facilitation theory was first applied, the claimant was the owner of a Peruvian money exchange. The facts of the case suggest that the claimant knew that the transactions through his accounts were unusual and

158. See supra text accompanying notes $68-70$.

159. 19 U.S.C. $\S 1615$ (1988).

160. See supra text accompanying note 57.

161. In United States v. All Funds on Deposit in Great Eastern Bank, 804 F. Supp. 444, 447 n.5 (E.D.N.Y. 1992), the prosecutors argued that even if seizure of some of the money in an account could not be justified under a facilitation theory, the government hoped that discovery would produce evidence that the money had been involved in a crime.

162. Judges declining to apply facilitation theory in a particular case have explained their decisions in terms of remoteness from the underlying criminal activity. E.g., United States v. Certain Accounts, 795 F. Supp. 391 , 398 (S.D. Fla. 1992) ("As the account in question becomes more distant from the initial illegal transaction, so too does probable cause to forfeit become more attenuated."); see also Marine Midland Bank, N.A. v. United States, Nos. 93 Civ. 0307, 0357, 1993 WL 158542, at *8 (S.D.N.Y. May 11, 1993) (citing Certain Accounts, 795 F. Supp. at 398), affd in part, remanded in part, 11 F.3d 1119 (2d Cir. 1993).

163. See, e.g., United States v. Certain Funds on Deposit, 769 F. Supp. 80, 84-85 (E.D.N.Y. 1991) ("Criminal activity such as money laundering largely depends upon the use of legitimate monies. . . . It is precisely the commingling of tainted funds with legitimate money that facilitates the laundering and enables it to continue."). 
that transfers of legitimate funds really did provide "cover" for proceeds of drug trafficking. ${ }^{164}$ The problem is to distinguish authentic facilitation from mere commingling.

Some courts, interpreting facilitation under the drug forfeiture statute, ${ }^{165}$ have held that to be subject to forfeiture, assets must have a "substantial connection [to] the underlying criminal activity." 166 One might try similarly to himit facilitation theory under the money laundering statute, ${ }^{167}$ but the test is not useful in that context for two reasons. First, the decisions do not make clear what constitutes a substantial connection. ${ }^{168}$ Second, and more importantly, the point of facilitation theory is that the mere commingling of funds is an independent act of facilitation; ${ }^{169}$ of necessity, the newly tamted money bears a substantial connection to that act of facilitation.

A test asking whether the comminghing of funds substantially facilitated money laundering would solve some, but not all, of the problems of the "substantial connection" test. The "substantial facilitation" test seems to reduce the likelihood of contamination of property belonging to innocent persons by transactions two or three tinnes removed from money laundering. However, the meaning of the word "substantial" is no more self-evident in this context than in the original test.

There is a more fundamental flaw in the "substantial facilitation" test, though. The more innocent the recipient of money appeared, paradoxically, the more substantially the transaction would facilitate money laundering. ${ }^{170}$ The in rem nature of forfeiture ac-

164. United States v. All Monies $(\$ 477,048.62)$ in Account No. 90-3617-3, 754 F. Supp. 1467, 1473-75 (D. Haw. 1991).

165. 21 U.S.C. § 881 (1988 \& Supp. V 1993).

166. E.g., United States v. Schifferli, 895 F.2d 987, 989 (4th Cir. 1990); see supra text accompanying notes $110-13$.

167. Cf. All Monies, 754 F. Supp. at 1475 ("Property may not be considered to have facilitated illegal activity unless there is a substantial connection between the property and the illegal activity.").

168. See United States v. RD 1, Box 1, 952 F.2d 53, 57 n.5 (3d Cir. 1991) (suggesting that the distinctions made in various tests are merely semantic). Similar problems exist in the original context of drug forfeiture. See supra text accompanying notes 110-13.

169. See United States v. All Funds Presently on Deposit, 832 F. Supp. 542, 560-61 (E.D.N.Y. 1993) (observing that each act of mixing funds would reset the statute of limitations).

170. For example, suppose a drug dealer pays his electric bill with the profits of his business, intending that such a commonplace transaction will let him use his gains inconspicuously. His transaction constitutes money laundering. See, e.g., United States v. Gar- 
tions has always been recognized as a fiction, serving as a proxy for some person's culpability. ${ }^{171}$ By looking at the degree of facilitation while ignoring intent, the "substantial facilitation" test could ratify the fiction while dispensing with reality.

The only standard that would truly protect the innocent is a test that would ask whether the possessor of the facilitating funds intended to facilitate money laundering at the time of commingling. This standard would clearly demarcate the limits of facilitation theory. Moreover, it also would prevent modern forfeiture laws from implicitly working a revival of forfeiture of estate, by giving claimants who are not entirely innocent a way to show that some of their assets did not meet the legal standard for facilitation.

The clarity of the intent-based standard would provide important protection. By plainly removing assets from the scope of forfeiture when prosecutors do not have probable cause to believe that the owner intended to facilitate money laundering, it would avert seizures of property that would not ultimately be subject to forfeiture. ${ }^{172}$ It also would deprive prosecutors of the power in terrorem to induce settlements by those who cannot afford to be without seized property that may not be subject to forfeiture. It further would provide claimants with a concrete way to defend against forfeiture actions, in contrast with the present vagaries of the remoteness test.

Even thougl conditioning forfeiture on the possessor's intent would be a good policy, the statutory language does not self-evidently support it. Nonetheless, exanination of intent would not merely be a judicial accretion to the statutory scheme. Why this is

cia-Emanuel, 14 F.3d 1469, 1474 (10th Cir. 1994) (holding that intent to conceal illegal source of assets turns a transaction into illegal money laundering). Since the money looks much more innocent after being deposited in the electric company's account than it did in the hands of the drug dealer, the utility's mixing of funds would seem to have substantially, but innocently, facilitated money laundering. Cf. United States v. Certain Accounts, 795 F. Supp. 391, 398 n.12 (S.D. Fla. 1992) (observing that facilitation theory would subject to seizure the account of a utility after a money launderer used tainted money to pay his bill).

171. Austin v. United States, 113 S. Ct. 2801, 2808-10 (1993).

172. Seizures in which the government "make[s] no allegations that [the asset] is controlled, nominally or effectively, by anyone with even a partially illegal purpose," Marine Midland Bank, N.A. v. United States, Nos. 93 Civ. 0307, 0357, 1993 -WL 158542, at *7 (S.D.N.Y. May 11, 1993), aff'd in part, remanded in part, 11 F.3d 1119 (2d Cir. 1993), are not extreme hypotheticals. Marine Midland involved a seizure of nearly eight million dollars under exactly those circumstances. Id.; see supra notes 130-31 and accompanying text. 
so is made clearer by asking what is facilitated. The answer is, money laundering. The forfeiture statute ${ }^{173}$ provides for forfeiture of property "involved im" money laundering, and facilitation theory is based on the notion that property that facihtates money laundering is mvolved in it. ${ }^{174}$ Yet the offense of money laundering is defined by statute as follows:

[C]onduct[ing] or attempt[ing] to conduct [a transaction] which in fact involves the proceeds of specified unlawful activity-(A)(i) with the intent to promote the carrying on of specified unlawful activity; or... (B) knowing that the transaction is designed .... (i) to conceal or disguise the nature, the location, the source, the ownership, or the control of the proceeds. ${ }^{175}$

Defining facilitation of this offense is particularly tricky because the property involved is money. The point of laundering money is to become able to spend and invest it, but it does not follow that any action taken with the inoney for the launderer's benefit subsequent to an illegal transaction has facilitated that earher, illegal transaction. ${ }^{176}$ Merely mixing clean and dirty money should not in itself be grounds for forfeiture. On the other hand, if the possessor of the inoney has the statutorily required intent when the commingling occurs, a new violation of the statute has occurred. In that case, the facilitation is wrongful, and the strongest case for forfeiture exists.

The intent test explains clearly why an interbank account involved in routine transactions is not subject to forfeiture, ${ }^{177}$ but why all funds in a transaction made by someone suspected of money laundering are forfeitable. ${ }^{178}$ Probable cause for seizure would also exist when a person accepts a large cash payment froin

173. 18 U.S.C. \& 981 (1988 \& Supp. IV 1992).

174. See supra text accompanying notes $98-99$.

175. 18 U.S.C. \& 1956(a)(1) (1988 \& Supp. IV. 1992) (emphases added).

176. See, e.g., United States v. Sanders, 928 F.2d 940, 946 (10th Cir.) (rejecting broad construction of 18 U.S.C. $\& 1956$ (1988 \& Supp. IV 1992) because the government's version would criminalize spending money, not laundering it), cert. denied, $112 \mathrm{~S}$. Ct. 142 (1991).

177. Cf. Marine Midland Bank, N.A. v. United States, Nos. 93 Civ. 0307, 0357, 1993 WL 158542 at *8, (S.D.N.Y. May 11, 1993) (finding interbank account not subject to seizure or forfeiture), aff'd in part, remanded in part, 11 F.3d 1119 (2d Cir. 1993).

178. Cf. United States v. All Monies $(\$ 477,048.62)$ in Account No. 90-3617-3, 754 F. Supp. 1467, 1475-76 (D. Haw. 1991) (ordering forfeiture of money that had been involved in suspicious transfers made by Peruvian money exchanger). 
someone who has no known legally acquired assets. If the payment were subsequently divided between several existing accounts, probable cause would exist that the recipient was trying to hide the money among legitimate accounts, rendering the accounts subject to seizure. Finally, in most cases, the government will be able to establish probable cause as to all of a money launderer's accounts merely by showing probable cause that the person was laundering money. The new standard would give the launderer an opportunity after seizure to defend against forfeiture by showing that he was not laundering money in a transaction, but merely spending or investing it.

These examples assume that knowledge, not purpose, is sufficient intent to support forfeiture. Arguably, based on the history of forfeiture, the required scienter could be as low as negligence. ${ }^{179}$ However, the distinction between innocent commingling of funds and wrongful facilitation of money laundering ${ }^{180}$ indicates that the proper standard is knowledge. ${ }^{181}$ Knowledge is circumstantial evidence of purpose, moreover, and considering that the government needs to show only probable cause to seize assets, there will be very few cases that present a practical difference between knowledge and purpose.

Admittedly, focus on intent is probably not required by the Constitution. Forfeiture without an explicit showing of the owner's wrongful imtent or knowledge of criminal use is well established in the United States. ${ }^{182}$ Although the Supreme Court recently held in Austin that the Eighth Amendment's prohibition of excessive fines applies to forfeitures, Justice Scalia's concurrence suggested that the Constitution may require only that to be subject to forfei-

179. See supra notes $30-31,58$ and accompanying text.

180. See supra text accompanying note 176.

181. See 18 U.S.C. \$§ 1956-1957 (1988 \& Supp. IV 1992) (specifying knowledge as element of crime of money laundering).

182. See, e.g., J.W. Goldsmith, Jr.-Grant Co. v. United States, 254 U.S. 505, 510-11 (1921); Dobbins's Distillery v. United States, 96 U.S. 395, 399 (1877) ("Nor is it necessary that the owner of the property should have knowledge that the lessee and distiller was committing fraud on the public revenue, in order that the information of forfeiture should be maintained."); see also Calero-Toledo v. Pearson Yacht Leasing Co., 416 U.S. 663, 680 (1974) (rejecting innocence of owner as defense to forfeiture under Puerto Rico law). But cf. Austin v. United States, 113 S. Ct. 2801, 2816 (1993) (Kennedy, J., concurring) (forfeiture when owner has committed no wrong, intentional or negligent, would raise "a serious constitutional question"). 
ture, property must bear a sufficiently close relation to the underlying offense. ${ }^{183}$

Further, concerns about those who neither knew about nor consented to the underlying crime may be regarded as sufficiently addressed by the innocent owner defense. Innocent parties, although deprived of the use of their property until they can demonstrate their innocence, ultimately lose only the proceeds of the crime traced to the imnocent owner plus the price of establishing their defense. This penalty can be justified on the grounds that those who deal with money launderers are in the best position to do something about money laundering and that the threat of this deprivation gives them an appropriate incentive. ${ }^{184}$

However, any argument against intent as a standard, if it were otherwise valid, would prove too much. If the facilitation theory as advanced by prosecutors were vahi, the entire Federal Reserve system would theoretically be subject to seizure, regardless of whether a bank or an account holder had personally dealt with a criminal or not. ${ }^{185}$ Although courts would not likely uphold egregious seizures, the prosecutors' argument leaves the courts with no guidance in their decisions other than a particular judge's sense of what constitutes an egregious seizure.

Moreover, the broader theory also provides hittle guidance to prosecutors. Thus, prosecutors would have almost complete discretion to seize large sums of money and make the owners try to get it back. Even exercising the utmost integrity, a prosecutor lias no articulable standard to guide the linnts of seizure under the facilitation theory. Furtler, some claimants will be unable to afford to challenge forfeiture, especially after the money they need to hire counsel has been seized by the government, and otlers will find their defenses hindered by the lack of a clear standard. Consider-

183. See Austin, 113 S. Ct. at 2815 (Scalia, J., concurring).

184. Cf. United States v. Park, 421 U.S. 658, 671 (1975) (affirming conviction of responsible corporate officer for violation of Federal Food, Drug, and Cosmetic Act of 1938, 21 U.S.C. $\$ \S 301-393$ (1988 \& Supp. V 1993), despite lack of criminal intent, because official can prevent violation "with no more care than society might reasonably expect and no more exertion than it might reasonably exact from one who assumed his responsibilities" (citing Morissette v. United States, 342 U.S. 246, 256 (1952))).

185. See Marine Midland Bank, N.A. v. United States, Nos. 93 Civ. 0307, 0357, 1993 WL 158542, at $* 8$ (S.D.N.Y. May 11, 1993) (observing that facilitation theory would cause tainted funds to "wreak havoc upon the international banking system"), aff'd in part, remanded in part, 11 F.3d 1119 (2d Cir. 1993). 
ing some of the prosecutors' incentives for broad seizure, ${ }^{186}$ courts should not leave these decisions to prosecutors with so little constraint, especially because Congress has not clearly expressed a desire to give them such discretion.

Looking to intent would not substantially hinder prosecutors' ability to reach assets that are truly involved in drug dealing or money laundering. Proceeds of these crimes in the possession of banks would remain subject to forfeiture, and the costs of defending actions for forfeiture of these assets should still give banks an incentive to stay away from money launderers. As for inoney launderers themselves, the government needs to show inerely probable cause to believe that an asset is subject to forfeiture before shifting the burden to the owner to prove otherwise; ${ }^{187}$ in many cases, prosecutors would be able to make this initial showing as to substantially all of a money launderer's assets. To require prosecutors to show imtent would be an extra burden, but it usually would be light due to the low standard of proof. Moreover, prosecutors must already show that at least one person liad criminal intent, because intent is an element of the substantive offense of money laundering. ${ }^{188}$ Further, the fungible property forfeiture statute ${ }^{189}$ drastically reduces criminals' ability to immunize assets from forfeiture by creatively shifting money around.

Ultimately, this proposed standard would not substantially mcrease the burden on prosecutors, because many courts lave implicitly rehed on intent already. In All Monies, the first facilitation theory case, the court could infer intent to use the legitimate funds to cover a transfer of tainted money because the claimant liad engaged in unusual transactions originating in a country known to be a major source of drugs. ${ }^{190}$ Conversely, in Marine

186. See supra note 150 .

187. See supra notes $68-74$ and accompanying text.

188. 18 U.S.C. $\$ \S 1956-1957$ (1988 \& Supp. IV 1992). Probable cause to believe that an asset is involved in money laundering logically requires probable cause that money laundering has occurred. See United States v. All of the Inventories of the Businesses Known as Khalife Bros. Jewelry, 806 F. Supp. 648, 650-51 (E.D. Mich. 1992) ("[U]nder 18 U.S.C. \& 981(a)(1)(A) the government must establish probable cause to believe that a substantial connection exists between the property to be forfeited ... and the facilitation of illegal money laundering violations or currency reporting violations."). Probable cause that the offense has been committed itself implies probable cause as to all the elements of that offense.

189. 18 U.S.C. \& 984 (Supp. IV 1992).

190. See United States v. All Monies $(\$ 477,048.62)$ in Account No. 90-3617-3, 754 F. Supp. 1467, 1474-75 (D. Haw. 1991). 
Midland Bank, the court found that no intent was present when a clearing bank bundled funds for transfer to the United States and thus held that the untainted funds were not subject to seizure or forfeiture. ${ }^{191}$

Courts have already started to recognize this principle. In United States v. Contents of Account Numbers 208-06070 \& $208-06068-1-2,{ }^{192}$ the court treated intent as dispositive:

The facilitation theory is appropriate in the present case where the government has demonstrated probable cause to believe that [the claimant] established and controlled the Six Accounts [at issue in the forfeiture action], and commingled legitimate and illegitimate funds in these accounts, for the purpose of disguising the nature and source of the proceeds of his [criminal] scheme. ${ }^{193}$

Thus, treating intent as an element of facilitation would permit the clarification of many past decisions and provide a rational principle to guide judges, prosecutors, and claimants. By providing gnidance, it imight prevent innocent persons from being deprived of property pending a forfeiture action that would not succeed under present law. Judge Easterbrook wrote, "Bank accounts do not commit crimes; people do. It makes no sense to confiscate whatever balance happens to be in an account bearing a particular number, just because proceeds of crime once passed through that account. ${ }^{\text {"194 }}$ Looking to the possessor's intent would allow courts to distinguish those cases in which money facilitated laundering and those in which funds were "just passing through."

\section{CONCLUSION}

Limiting the scope of forfeiture to assets involved in transactions im which the possessor intends to launder money would protect the innocent without unduly burdening prosecutors. Under the intent-based standard, people would be protected from having heavy costs imposed on the basis of only probable cause, and wrongdoers would not be autonatically deprived of the right to

191. Marine Midland Bank, N.A. v. United States, Nos. 93 Civ. 0307, 0357, 1993 WL 158542, at *7-*8 (S.D.N.Y. May 11, 1993), aff'd in part, remanded in part, 11 F.3d 1119 (2d Cir. 1993).

192. 847 F. Supp. 329 (S.D.N.Y. 1994).

193. Id. at 335 .

194. United States v. $\$ 448,342.85,969$ F.2d 474, 476 (7th Cir. 1992). 
own property. Prosecutors still would have the weapons of burdenshifting and the substitute assets provision to effect the will of Congress and seize the fruits of crime. Moreover, this standard is already implicit im many cases; it ought to be made explicit to make the jurisprudence coherent and to protect the innocent. 